\title{
Mechanism and Influencing Factors of REY Enrichment in Deep-Sea Sediments
}

\author{
Jiangbo Ren ${ }^{1,2} \mathbb{D}$, Yan Liu ${ }^{1,3, *}$, Fenlian Wang ${ }^{1,2}$, Gaowen He ${ }^{1,2, *}$, Xiguang Deng ${ }^{1,2}$, Zhenquan Wei ${ }^{1,2}$ \\ and Huiqiang Yao ${ }^{1,2}$
}

check for updates

Citation: Ren, J.; Liu, Y.; Wang, F.; He, G.; Deng, X.; Wei, Z.; Yao, H. Mechanism and Influencing Factors of REY Enrichment in Deep-Sea Sediments. Minerals 2021, 11, 196. https://doi.org/10.3390/min11020196

\section{Academic Editor:}

Argyrios Papadopoulos

Received: 15 December 2020

Accepted: 10 February 2021

Published: 13 February 2021

Publisher's Note: MDPI stays neutral with regard to jurisdictional claims in published maps and institutional affiliations.

Copyright: (c) 2021 by the authors. Licensee MDPI, Basel, Switzerland. This article is an open access article distributed under the terms and conditions of the Creative Commons Attribution (CC BY) license (https:/ / creativecommons.org/licenses/by/ $4.0 /)$.
1 Southern Marine Science and Engineering Guangdong Laboratory (Guangzhou), Guangzhou 511458, China; dourjb222@163.com (J.R.); fenlian0523@163.com (F.W.); dengxg68@163.com (X.D.); wei_zhenquan@163.com (Z.W.); hqyao@163.com (H.Y.)

2 Key Laboratory of Marine Mineral Resources, Ministry of Natural Resources, Guangzhou Marine Geological Survey, Guangzhou 510075, China

3 Key Laboratory of Deep-Earth Dynamics of Ministry of Natural Resources, Institute of Geology, Chinese Academy of Geological Science, Beijing 100037, China

* Correspondence: ly@cags.ac.cn (Y.L.); hegaowen@163.com (G.H.)

\begin{abstract}
Deep-sea sediments with high contents of rare-earth elements and yttrium (REY) are expected to serve as a potential resource for REY, which have recently been proved to be mainly contributed by phosphate component. Studies have shown that the carriers of REY in deep-sea sediments include aluminosilicate, Fe-Mn oxyhydroxides, and phosphate components. The $\sum R E Y$ of the phosphate component is 1-2 orders of magnitude higher than those of the other two carriers, expressed as $\sum \mathrm{REY}=0.001 \times\left[\mathrm{Al}_{2} \mathrm{O}_{3}\right]-0.002 \times[\mathrm{MnO}]+0.056 \times\left[\mathrm{P}_{2} \mathrm{O}_{5}\right]-32$. The sediment $\mathrm{P}_{2} \mathrm{O}_{5}$ content of $1.5 \%$ explains $89.1 \%$ of the total variance of the sediment $\sum$ REY content. According to global data, $\mathrm{P}$ has a stronger positive correlation with $\sum \mathrm{REY}$ compared with $\mathrm{Mn}, \mathrm{Fe}, \mathrm{Al}$, etc.; $45.5 \%$ of samples have a $\mathrm{P}_{2} \mathrm{O}_{5}$ content of less than $0.25 \%$, and $\sum \mathrm{REY}$ of not higher than $400 \mathrm{ppm}$. The $\sum$ REY of the phosphate component reaches $n \times 10^{4} \mathrm{ppm}$, much higher than that of marine phosphorites and lower than that of REY-phosphate minerals, which are called REY-rich phosphates in this study. The results of microscopic observation and separation by grain size indicate that the REY-rich phosphate component is mainly composed of bioapatite. When $\sum R E Y>2000$ ppm, the average $\mathrm{CaO} / \mathrm{P}_{2} \mathrm{O}_{5}$ ratio of the samples is 1.55 , indicating that the phosphate composition is between carbonate fluoroapatite and hydroxyfluorapatite. According to a knowledge map of sediment elements, the phosphate component is mainly composed of $\mathrm{P}, \mathrm{Ca}, \mathrm{Sr}, \mathrm{REY}, \mathrm{Sc}, \mathrm{U}$, and Th, and its chemical composition is relatively stable. The phosphate component has a negative Ce anomaly and positive $\mathrm{Y}$ anomaly, and a REY pattern similar to that of marine phosphorites and seawater. After the early diagenesis process (biogeochemistry, adsorption, desorption, transformation, and migration), the REY enrichment in the phosphate component is completed near the seawater/sediment interface. In the process of REY enrichment, the precipitation and enrichment of $\mathrm{P}$ is critical. According to current research progress, the REY enrichment is the result of comprehensive factors, including low sedimentation rate, high $\sum$ REY of the bottom seawater, a non-carbonate depositional environment, oxidation conditions, and certain bottom current conditions.
\end{abstract}

Keywords: rare earth elements and yttrium; REY-rich phosphate; enrichment mechanism; deep-sea sediments; knowledge map; linear regression

\section{Introduction}

Rare earth elements and yttrium (REY) are important strategic resources. With the increasing demand of high-tech products and green-tech applications, and gradual depletion of easily processed REY resources, diversified REY resources are urgently needed to ensure a stable supply. In particular, heavy REY (HREY) resources appear scarce; $95 \%$ of these elements are exclusively produced from ion-absorption-type ore deposits in southern 
China [1,2]. The mining of ion-adsorption-type ore causes environmental damage, and the supply of HREY may be at risk. However, in recent years, a certain type of deep-sea sediment enriched in REY and HREY, readily recovered from samples by simple acid leaching, is expected to serve as a potential source of REY [3-5].

REY-rich deep-sea sediments were first discovered in the central North Pacific and southwestern Pacific [4], and subsequently reported across most of the Pacific, Indian, and Atlantic oceans (Figure 1) [3,6-9]. At present, deep-sea sediments in the western Pacific have the greatest resource potential, with the REY content ( $\Sigma R E Y)$ in the enrichment layer as high as $7974 \mathrm{ppm}$ off Minamitorishima Island [1,3,6,9].

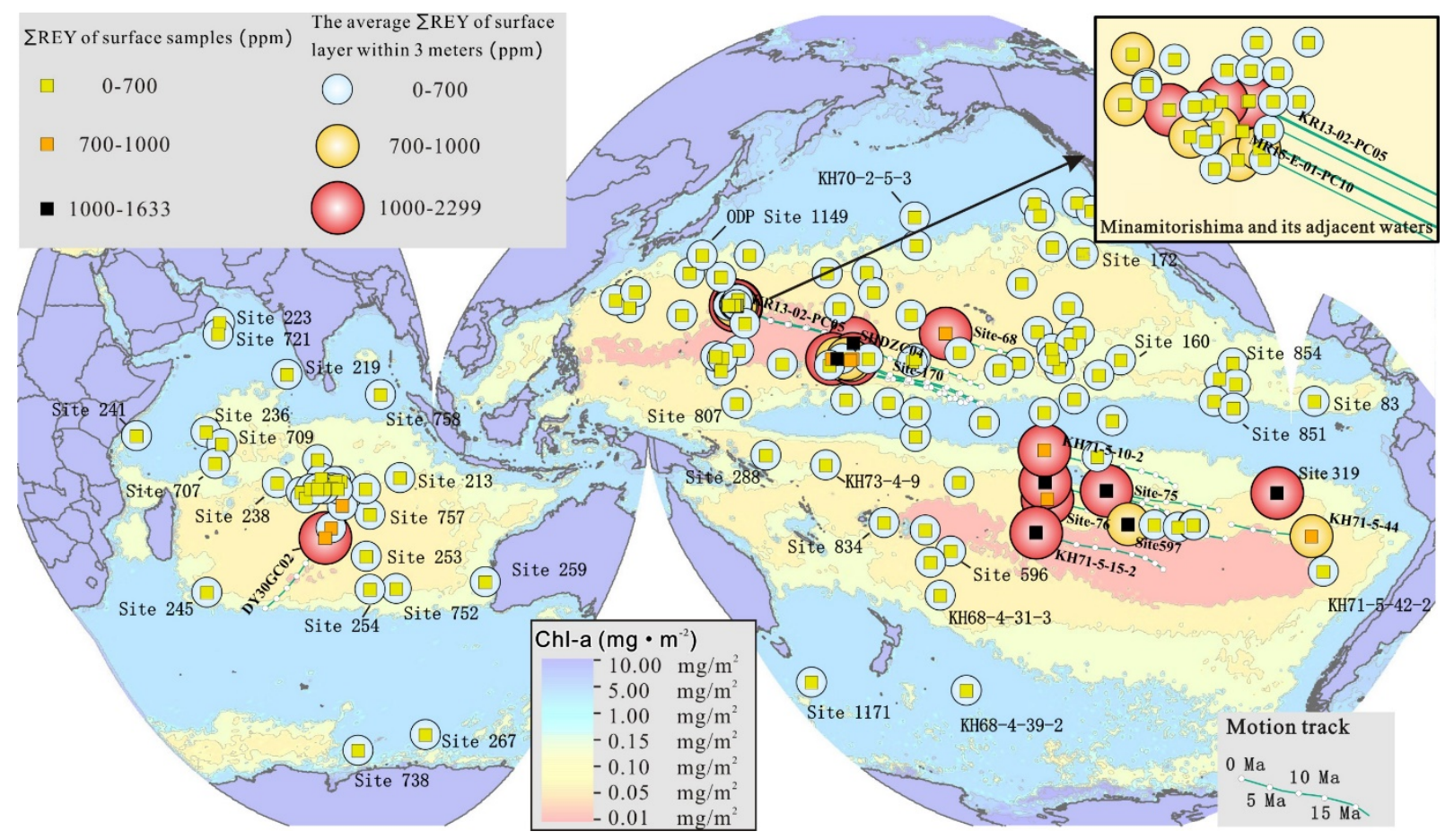

Figure 1. Contents of REY ( $R$ REY) in surface and surface layer within $3 \mathrm{~m}$ samples of deep-sea sediments from the Pacific and Indian oceans. Data are from [1,3,4,6-8,10-15]. The motion track is $5 \mathrm{Ma}$ / point, and the data are from [16]. The data of Chl-a (chlorophyll content) in surface seawater are from [17].

Studies reveal that phillipsite, clay minerals, Fe-Mn oxyhydroxides, and phosphate components are all REY carrier phases [10,18]. These phases prefer to accumulate in slow sedimentary environments, and so it is difficult to define the contribution of various components. Recent studies have further confirmed that the $\sum R E Y$ of clay and phillipsite themselves are not high, with $\sum$ REY generally not exceeding $256 \mathrm{ppm}[19,20]$. Under the weak influence of phosphate components $\left(\mathrm{P}_{2} \mathrm{O}_{5}<0.25 \%\right), \Sigma R E Y$ has a certain positive correlation with $\mathrm{Al}_{2} \mathrm{O}_{3}$ content. However, in REY-rich deep-sea sediments, the contribution of phillipsite or clay minerals to REY enrichment is easily masked by the phosphate component.

Fe-Mn oxyhydroxides have strong adsorption capacity, and hydrogenetic Fe-Mn nodules can greatly enrich REY (LREY, excepting Ce, generally reaches 2000 ppm) [21]. The REY enrichment of metalliferous sediment in the Southeastern Pacific was initially thought to be related to hydrothermal processes [4]. However, there is no significant correlation between $\sum$ REY and the Fe and Mn contents in deep-sea sediments. Moreover, the $\sum R E Y$ of Fe-Mn micronodules in deep-sea sediments is relatively low (246-333 ppm) [20]. The $\sum$ REY of hydrothermal Fe-Mn deposits is 1-2 orders of magnitude lower than that of hydrogenetic Fe-Mn deposits; rapid hydrothermal processes have an obvious dilution effect on REY [22]. Recent comparison of fine-grained analyses of samples from the South- 
east Pacific and central North Pacific show that apatite is the main host of REY, even in metalliferous deep-sea sediments near the East Pacific Rise [23].

The results of in situ analyses of bioapatite and chemical leaching of phosphate component from deep-sea sediments showed that the $\sum R E Y$ of the phosphate component was 1-2 orders of magnitude higher than that of other REY carriers [3,12,19,24]. Among the major oxides of deep-sea sediment samples, $\sum R E Y$ and $\mathrm{P}_{2} \mathrm{O}_{5}$ always maintain a strong positive correlation. The results show that the REY patterns of deep-sea sediments are similar to those of marine phosphates. The higher the content of $\Sigma R E Y$, the closer their REY patterns are $[6,12,25]$. The $\mathrm{P}$ in deep-sea sediments mainly exists in the form of REY-rich phosphate, and changes in the P content have a significant influence on the content and patterns of REY [12]. In summary, these studies have indicated that the high $\Sigma$ REY of deep-sea sediments is closely related to the phosphate component. However, not all $\mathrm{P}$ forms REY-rich phosphates.

In addition to the above studies, lots of studies have discussed the mechanism of REY enrichment in deep-sea sediments from the perspectives of the marine P cycle, sedimentation rate, sediment types, redox conditions, water $\sum R E Y$, and bottom ocean current $[4,6,26-28]$. However, there is a lack of quantitative research and systematic review of the contribution of phosphate components to REY enrichment, and in-depth discussion on the mechanism of phosphate components on REY enrichment is needed. The contribution of phosphate components to REY enrichment and the study of REY enrichment mechanisms in deep-sea sediments are of great significance for determining regions with high resource potential and for revealing the potential relationships between the geodynamic system and marine mineral resources. In this study, on the basis of compiling a large volume of chemical data and related environmental parameters of deep-sea sediment sites, the temporal and spatial distributions of REY-rich deep-sea sediments were summarized. Then the contribution of phosphate components to REY in deep-sea sediments was determined qualitatively and quantitatively, and the characteristics of phosphate components were described from chemical composition and microscopic identification results. Finally, the enrichment process of REY and the influencing factors of REY enrichment in deep-sea sediments were considered.

\section{Types and Distribution of REY-Rich Deep-Sea Sediments}

Based on the analysis of more than 2000 samples from 78 cores in the Pacific Ocean, Kato et al. (2011) found that most deep-sea sediments in the Southeast Pacific and central North Pacific have high $\Sigma$ REY (400-2230 ppm for $\Sigma$ REY and 70-430 ppm for $\Sigma H R E Y$ ). These REY-rich deep-sea sediments are comparable with ion-adsorption clay-type deposits of South China, and may be potential REY resources [4]. At present, the Western Pacific sediments have the most resource potential, and the highest $\Sigma R E Y$ in the sediments off Minamitorishima Island is 7974 ppm [1]. Tanaka et al. (2020) further classified the REY-rich deep-sea sediments into "ordinary REY-rich mud" ( $\Sigma$ REY = 400-2000 ppm), "highly REYrich mud" ( $\Sigma$ REY = 2000-5000 ppm) and "extremely REY-rich mud" ( $\Sigma$ REY > 5000 ppm). Owing to the remarkably high content of REY (especially of HREY), extremely/highly REY-rich deep-sea sediments have attracted great attention as an unconventional and promising mineral resource for REY [6].

We collected the chemical data of 6088 samples from 177 sites in the Pacific Ocean, Indian Ocean, and Atlantic Ocean (Table S1), and calculated the $\sum R E Y$ of surface sediments, the average $\sum R E Y$ of surface layers within $3 \mathrm{~m}$, the maximum $\sum R E Y$, sedimentation rate, bottom water oxygen concentration, and seafloor megafaunal biomass at each site (Table S2). The water depths of sites with $\sum$ REY more than 1000 ppm are mainly concentrated between 4180 and $5160 \mathrm{~m}$, indicating that REY-rich deep-sea sediments are mainly developed below the carbonate compensation depth (CCD). There are 18 cores where the average $\sum R E Y$ of surface layers within 3 m exceeds 1000 ppm; these mainly developed off Minamitorishima Island of the Western Pacific Ocean, the central North Pacific Ocean, the Southeast Pacific Ocean, and the central Indian Ocean basin. The surface sediments are relatively easy to trace 
back to the relevant marine environment, which can provide an important reference for the REY mechanism. Current studies have confirmed that $\mathrm{P}$ is the basis for the REY enrichment in deep-sea sediments. However, the P enrichment in deep-sea sediments cannot be simply understood as the high biogenic potential of surface seawater. For example, the REY-rich sediments in the Western Pacific are located on the edge of a typical tropical oligotrophic sea area. The distribution of global chlorophyll content (Figure 1) is very close to that of average surface productivity [29]. According to current data, REY-rich deep-sea sediments tend to develop in relatively low chlorophyll sea areas (Figure 1), indicating relatively low biological productivity. The bottom water oxygen concentration far from the coast is generally high [29], indicating a condition of relative oxidation. Therefore, it is difficult to understand the reasons for the REY contents of sediments from current redox data. However, the sedimentation rates of these sites are quite different, and the REY-rich deepsea sediments are obviously developed in places with relatively low sedimentation rates.

There are 16 sites off Minamitorishima Island with $\sum$ REY of more than 4000 ppm; these are considered as the most resource potential area. At present, there is no economic feasibility evaluation of REY resources in deep-sea sediments, and there is also a lack of excavation technology. Surface sediments are always used in REY beneficiation and metallurgy experiments, and so are more representative of enrichment of REY in surface layers. However, the $\sum$ REY of surface samples off Minamitorishima Island are relatively low, with the average $\sum R E Y$ of samples within $3 \mathrm{mbsf}$ (meters below sea floor) exceeding 1000 ppm from only six sites (Table S2). The $\sum$ REY of the samples at $2.28 \mathrm{mbsf}$ and $2.78 \mathrm{mbsf}$ of site MR15-E01-PC05 are as high as 5619 and 6323 ppm, respectively, which increases the average $\sum R E Y$ of the samples within 3 mbsf to 2299 ppm [6].

The $\sum R E Y$ in Indian Ocean sediments is generally low; only the average $\sum R E Y$ of samples within 3 mbsf at site DY30GC02 is $>1000$ ppm [7]. Samples with $\sum R E Y$ of up to 1113 ppm exist at site ODP-213, but they are located at $119 \mathrm{mbsf}$ [30]. Menendez et al. (2017) reported 35 samples of 32 sites recovered from the Atlantic Ocean, on a transect along $\sim 24^{\circ} \mathrm{N}$, most of which lacked surface sediment data. Samples from the Atlantic were too few and had the lowest $\sum R E Y$, with only two sites above $400 \mathrm{ppm}$ and a maximum of 513 ppm [31].

The $\sum R E Y$ in Pacific sediments are systematically higher than those in the Indian Ocean (Figure 2). The data for samples with ages of older than $60 \mathrm{Ma}$ are limited to just 596 sites, with $\sum R E Y$ generally $>1000$ ppm. More REY-rich deep-sea sediments have been recovered from the Pacific Ocean, but do not show strong geographical clustering. The sequence of $\Sigma R E Y$ enrichment in different types of deep-sea sediments is as follows: deep-sea clay $>$ hydrothermal sediment $>$ siliceous clay $>$ siliceous ooze $>$ calcium ooze [32]. The petrographic characteristics of REY-rich sediments are P-rich metalliferous sediment near the East Pacific ridge and P-rich phillipsite/clay components in other places $[4,9,26,30,31]$.

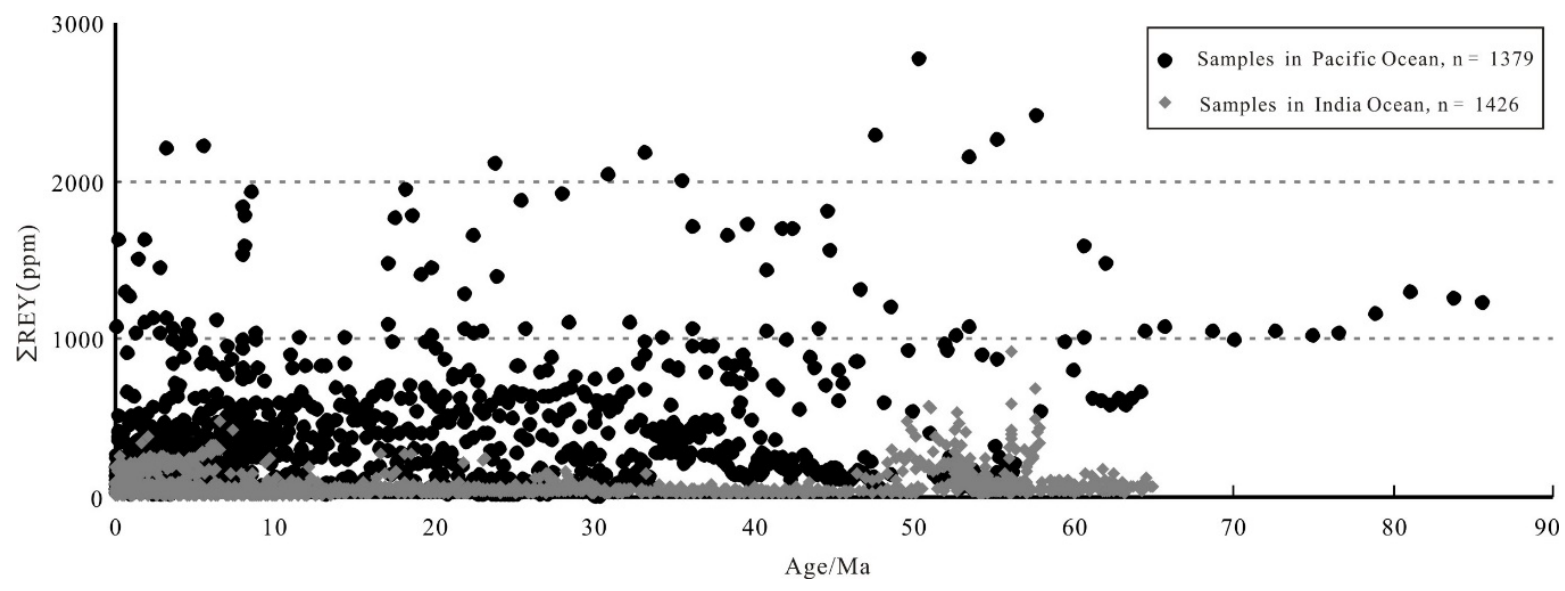

Figure 2. $\Sigma$ REY in deep-sea sediment samples as a function of age. Data sources as in Figure 1. 


\section{Phosphate Component and Its Enrichment Effect on REY}

\subsection{Contribution of Phosphate Component to REY Enrichment}

In recent years, there is increasing evidence to show that the high $\sum R E Y$ of deep-sea sediments is closely related to the phosphate component. Firstly, the results of correlation analysis show that only $\mathrm{P}$ content maintains a good correlation with $\sum R E Y$ compared with $\mathrm{Mn}, \mathrm{Fe}$, and $\mathrm{Al}$ (Figure 3). Moreover, most sites from different places show that $\sum R E Y$ variation is sensitive to $P$ content in vertical section $[1,9,10,13,15,33,34]$. For example, each layer of site KR13-02-PC05 shows $\sum R E Y$ to have strong correlations with $\mathrm{P}_{2} \mathrm{O}_{5}$ and $\mathrm{CaO}$ content, which is quite different from the relationship with other major oxides [9]. The $\mathrm{P}$ and $\mathrm{Ca}$ contents correlate positively (Figure 4), and the $\mathrm{CaO} / \mathrm{P}_{2} \mathrm{O}_{5}$ ratio is consistent with that of apatite $[20,35]$. The ratio of $\mathrm{CaO} / \mathrm{P}_{2} \mathrm{O}_{5}$ decreases gradually as $\sum \mathrm{REY}$ increases from low to high. When $\sum R E Y$ is $>4000$ ppm, the ratio of $\mathrm{CaO} / \mathrm{P}_{2} \mathrm{O}_{5}$ indicates that the phosphate component is between carbonate fluorapatite and hydroxyfluorapatite (Figure 5). Previous studies have shown that carbonate fluorapatite is the main P-bearing mineral in the oceans, and the $\mathrm{CaO} / \mathrm{P}_{2} \mathrm{O}_{5}$ also indicates that it is the main phosphate mineral in the deep-sea sediments [18]. With increasing $\sum R E Y$, the proportion of hydroxyfluorapatite in deep sea sediment increases. Microscopic identification has shown an abundance of bioapatite (e.g., fish teeth) in REY-rich deep-sea sediments [3,19,36].
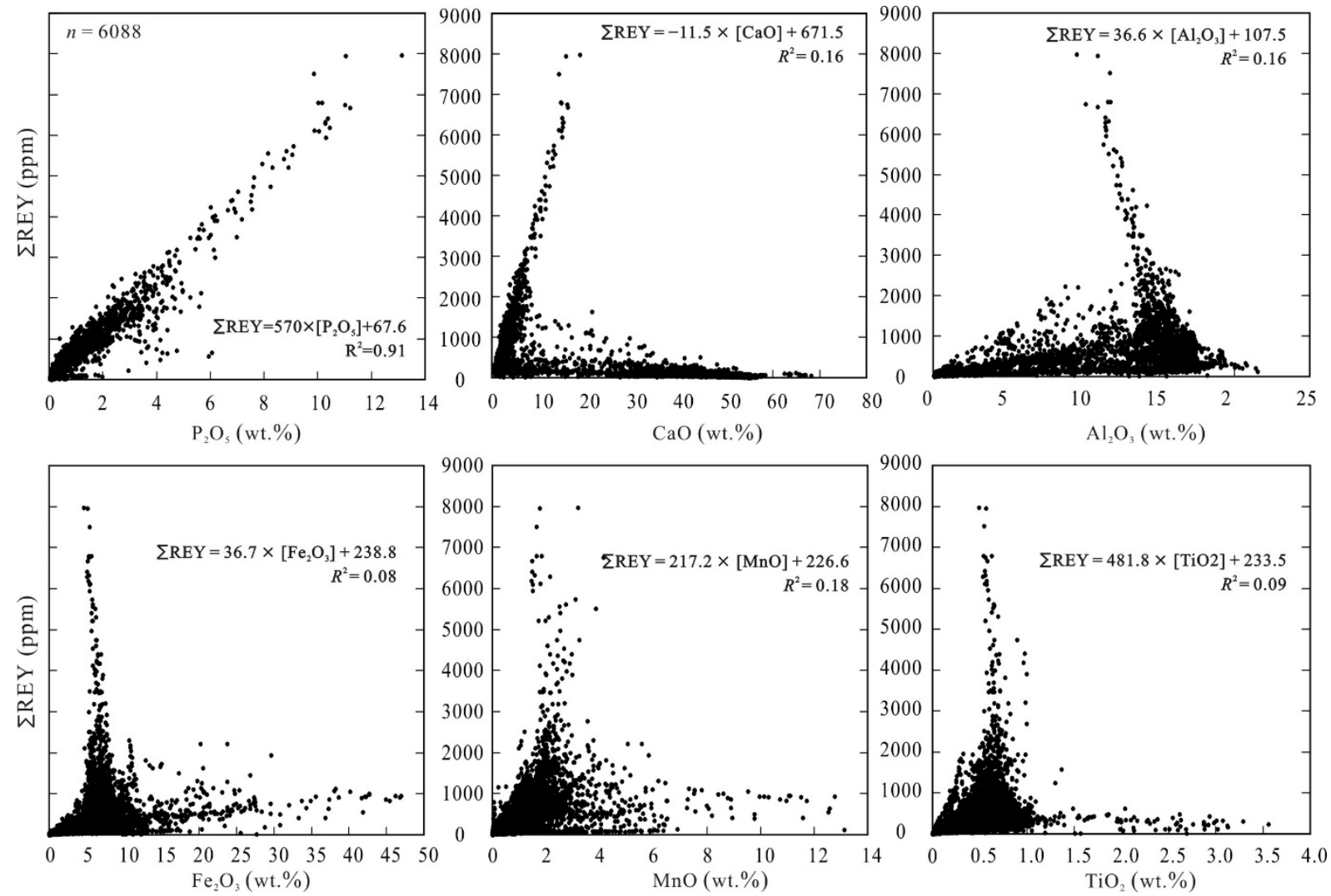

Figure 3. Correlations between $\Sigma$ REY and major oxides in deep-sea sediments; data sources as in Figure 1. 


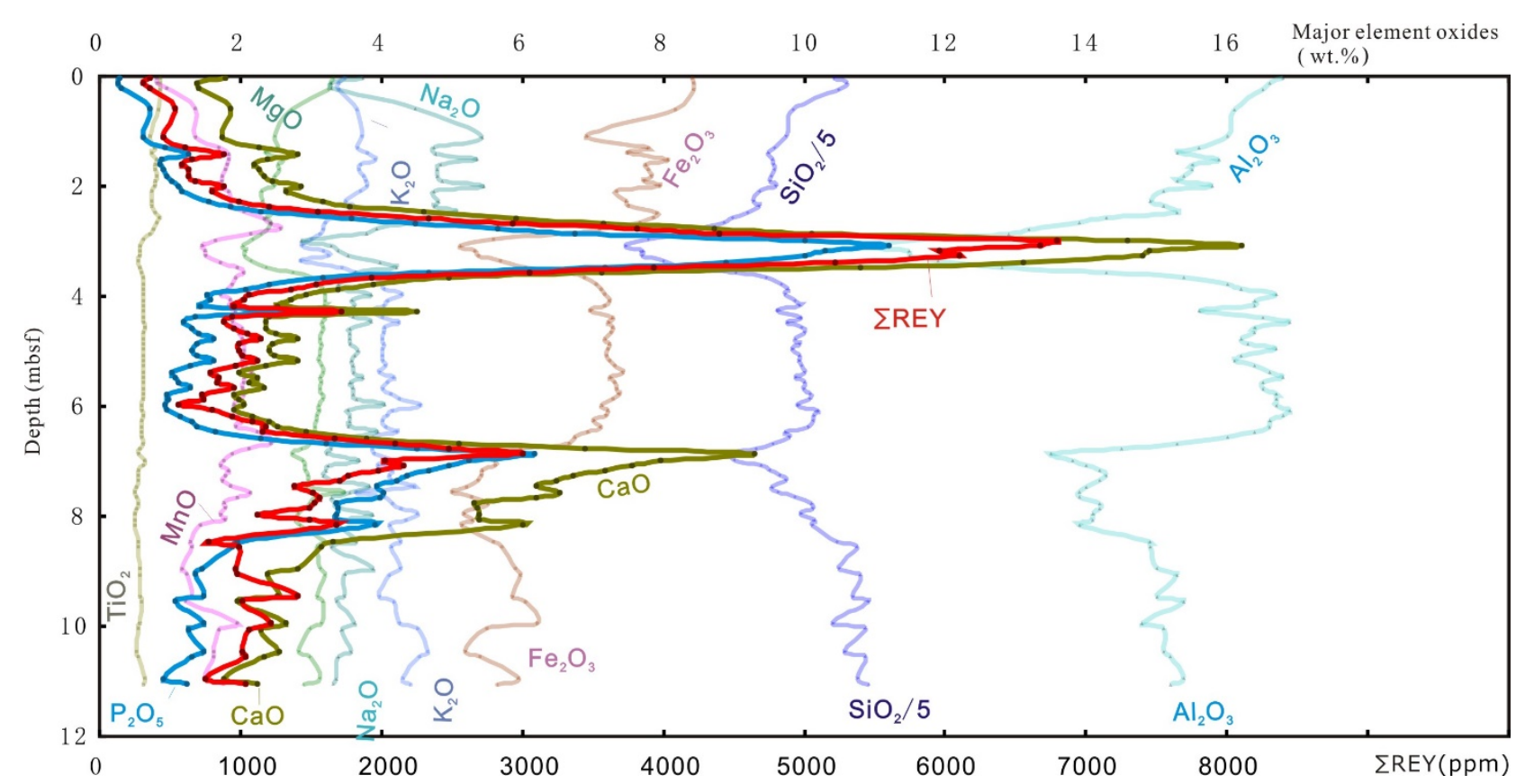

Figure 4. Relationship between the $\Sigma$ REY and the major oxides of samples at each layer at site KR13-02 PC05; data are from [9]. The units for $\sum R E Y$ are ppm; the units for oxides are weight percentage. The curves of $\Sigma \mathrm{REY} \mathrm{CaO}$, and $\mathrm{P}_{2} \mathrm{O}_{5}$ content are highly variable, showing obvious positive correlations.
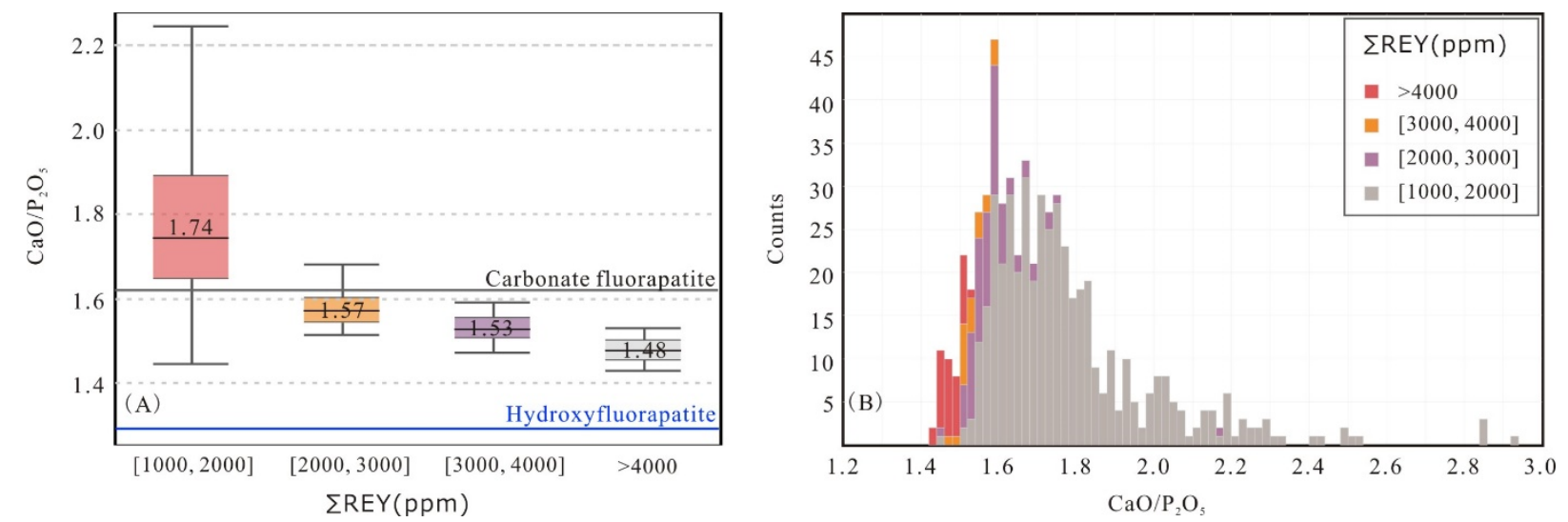

Figure 5. (A) $\mathrm{CaO} / \mathrm{P}_{2} \mathrm{O}_{5}$ box-plot diagram and (B) Frequency distribution histogram of sediment samples with different $\Sigma$ REY enrichment levels. The ranges of $\sum$ REY are 1000 to 2000 ppm, 2000 to 3000 ppm, 3000 to 4000 ppm, and more than $4000 \mathrm{ppm}$. The results show that the ratio of $\mathrm{CaO} / \mathrm{P}_{2} \mathrm{O}_{5}$ is more concentrated when $\sum R E Y$ exceeds 2000 ppm. Data sources as in Figure 1.

Secondly, the REY patterns of the REY-rich deep-sea sediments are very similar to those of marine phosphorites, showing an obvious Ce negative anomaly, Y positive anomaly, and no Eu anomaly (Figure 6A). The enrichment of REY in deep sea sediments is the result of the comprehensive action of aluminosilicates, phosphates, and other components [12,18]. The higher the $\sum R E Y$, the closer the REY patterns are to the phosphate component. Only samples with low $\sum$ REY from site KR13-02 PC05 may have flat or positive Ce anomalies (Figure 6A), indicating that the REY characteristics of aluminosilicates are exposed under low phosphate component contents. Regardless of whether the $\sum R E Y$ is high or low, the REY pattern of phosphate leaching from deep-sea sediments shows a significant negative $C$ e anomaly and positive $Y$ anomaly (Figure $6 \mathrm{~B}$ ). These characteristics indicate the importance of phosphate components in REY-rich deep-sea sediments for REY [12]. 

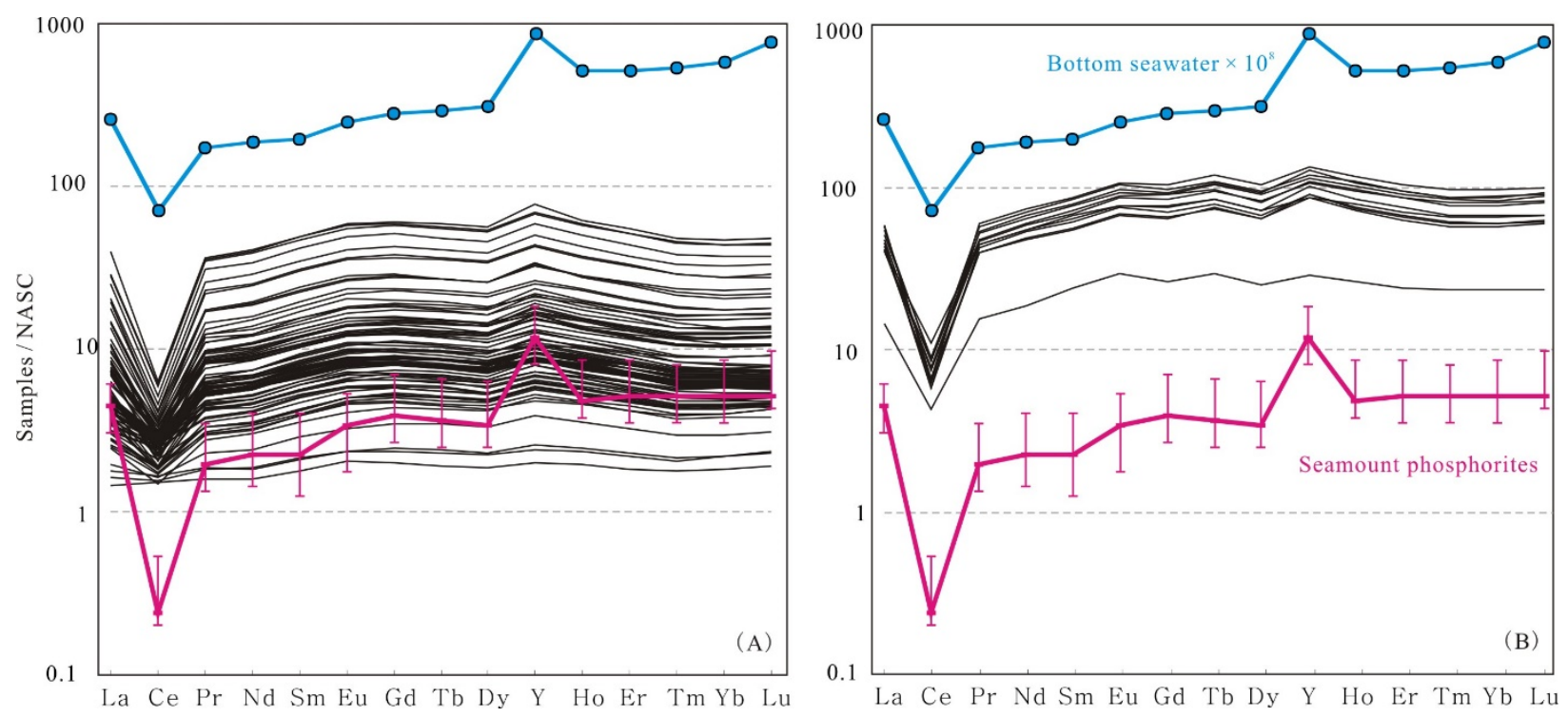

Figure 6. (A) NASC-normalized REY of each layer of site KR13-02 PC05; data from [9]. (B) Phosphate leaching from deep-sea sediments; data from [12]. NASC normalizing values are from [37]. Bottom seawater data is from [38]. Seamount phosphorites data is from [39].

Thirdly, if samples with $\mathrm{P}_{2} \mathrm{O}_{5}$ higher than $0.25 \%$ are excluded, the $\sum \mathrm{REY}$ of deep-sea sediment is not higher than $400 \mathrm{ppm}$ [12]. There are 2679 samples with $\mathrm{P}_{2} \mathrm{O}_{5} \leq 0.25 \%$, and the linear regression equation of $\sum R E Y$ and $\mathrm{Al}_{2} \mathrm{O}_{3}$ can be obtained as $\Sigma R E Y=0.001 \times \mathrm{Al}_{2} \mathrm{O}_{3}+48.6$, $R^{2}=0.77$. That is, under weak influence of the phosphate component $\left(\mathrm{P}_{2} \mathrm{O}_{5}<0.25 \%\right)$, $\sum R E Y$ has a certain correlation with the $\mathrm{Al}_{2} \mathrm{O}_{3}$ content. Although the contributions of phillipsite and clay minerals to REY enrichment are low, they do exist. However, this contribution is easily masked by that of the phosphate component.

Last but not least, the $\sum$ REY of the phosphate component in deep-sea sediments is extremely high. For example, the $\sum$ REY of in situ analyses of bioapatite samples is generally $n \times 10^{4} \mathrm{ppm}[3,19,24,36]$, and the average of $\sum R E Y$ in chemical separation results of the phosphate component reach 19,260 ppm [12]. Chemical phosphate precipitation involves fine particles that are difficult to analyze directly. According to the $\sum R E Y / \mathrm{P}_{2} \mathrm{O}_{5}$ ratio of bioapatite and whole sediment samples, authigenic $\mathrm{P}$ has a higher $\sum R E Y$ than bioapatite. In a word, the $\sum R E Y$ of the phosphate component reaches $\mathrm{n} \times 10^{4} \mathrm{ppm}$ (termed REY-rich phosphate in this study), which is much higher than that of marine phosphorites and lower than that of REY-phosphate minerals (e.g., monazite). Via quantitative analysis of process mineralogy, Liu et al. (2015) found that almost all REY exists in apatite [40]. In conclusion, the $\sum R E Y$ of the phosphate component is $~ 1-2$ orders of magnitude higher than that of other carriers; changes in the $\mathrm{P}$ content are very important for concentration and distribution REY in deep-sea sediments.

\subsection{Qualitative and Quantitative Understanding of Phosphate Components}

Knowledge maps of element correlations can show the kinship of elements. Element correlation coefficient analysis was carried out on 1200 samples from 49 sites off Minamitorishima Island, and the results are shown in Table S3. A knowledge map was constructed with elements or oxides as nodes and with correlation coefficients of greater than 0.5 as edges (Figure 7). 


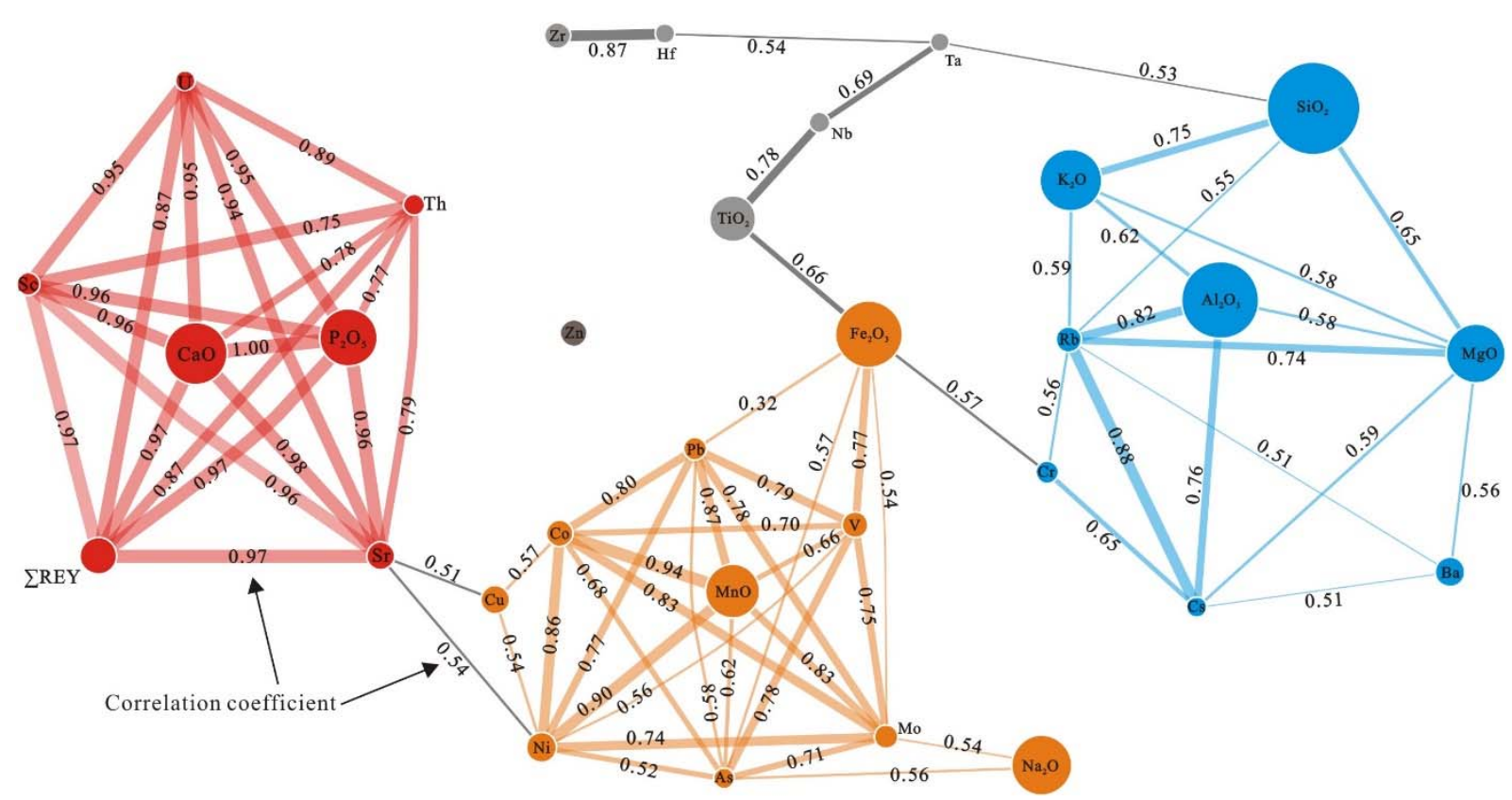

Figure 7. Knowledge map of element correlations for deep sea sediments off Minamitorishima Island; data are from Table S3. Node size reflects the average content of elements, and line thickness reflects the correlation coefficient between elements, which satisfies the following two formulas: nodes size $(\mathrm{mm})=\left(\operatorname{Ln}([\text { average content } \times 10])^{3}-7.8\right) \times 8 / 3660+2$. The units are as follows: average content, ppm; lines size, pound, which $=1.4 \times([$ related coefficient $]-0.5) / 0.5+0.1$.

According to the knowledge map, the elements of the deep-sea sediments can be divided into three categories: red nodes represented by $\mathrm{Cao}$ and $\mathrm{P}_{2} \mathrm{O}_{5}$ are the phosphate component, orange nodes represented by $\mathrm{MnO}$ and $\mathrm{Fe}_{2} \mathrm{O}_{3}$ are the $\mathrm{Fe}-\mathrm{Mn}$ oxyhydroxide component, and blue nodes represented by $\mathrm{SiO}_{2}$ and $\mathrm{Al}_{2} \mathrm{O}_{3}$ are the aluminosilicate component. It is clear that $\mathrm{P}, \mathrm{Ca}, \mathrm{Sr}, \mathrm{REY}, \mathrm{Sc}, \mathrm{U}$, and Th are the main elements associated with the phosphate component. These characteristics indicate that phosphate component has a relatively simple structure, while Fe-Mn oxyhydroxide and aluminosilicate components have more complicated chemical compositions (Figure 7).

The IBM SPSS Statistics 23 software was used to carry out multiple linear regression analysis on the compiled data; four quantitative relationship models were obtained (Table 1). Models 1, 2, and 3 are linear regression models of $\sum$ REY with $\mathrm{P}_{2} \mathrm{O}_{5}, \mathrm{Al}_{2} \mathrm{O}_{3}$, and $\mathrm{MnO}$ content based on all data; the models show that the influences of the phosphate, aluminosilicate, and Fe-Mn oxyhydroxide components on $\sum R E Y$ gradually decrease. Taking Model 3 as an example, $\Sigma$ REY $=0.056 \times\left[\mathrm{P}_{2} \mathrm{O}_{5}\right]+0.001 \times\left[\mathrm{Al}_{2} \mathrm{O}_{3}\right]-0.002 \times[\mathrm{MnO}]$ - 32.0, with $\mathrm{R}^{2}$ of 0.93 , which confirms the quantitative relationship between $\Sigma R E Y$ and the three components. From Model 3, the $\mathrm{P}_{2} \mathrm{O}_{5}$ enrichment capacity in relation to $\sum$ REY is 55 times that of $\mathrm{Al}_{2} \mathrm{O}_{3}$. According to this model, we can calculate the contribution of phosphate components to $\Sigma$ REY in each sample. The $\mathrm{P}_{2} \mathrm{O}_{5}$ content was divided into 22 groups at intervals of 0.5 , and the median of a box-plot was used to indicate the content trend of each group of data (Figure 8). From Figure 8, with increasing $\mathrm{P}_{2} \mathrm{O}_{5}$ content, the contribution of the phosphate component to $\sum R E Y$ increases rapidly. $\mathrm{A}_{2} \mathrm{O}_{5}$ content of $1.5 \%$ explains $89.1 \%$ of the total variance of the sediment $\sum$ REY content (Figure 8). Kato et al. (2011) and Ren et al. (2017) used dilute acids to reveal that almost all of the REY, except Ce, are readily leached from deep-sea samples $[4,12]$. The REY patterns are characteristics of marine phosphorites, indicating that the contribution of phosphate components to REY enrichment is consistent with our quantitative calculation results. 
Table 1. Multiples linear regression model between $\Sigma$ REY and major oxides (data sources as in Figure 1).

\begin{tabular}{ccc}
\hline Model & Linear Regression Equation (Data in ppm) & $\boldsymbol{R}^{\mathbf{2}}$ \\
\hline 1 & $\sum \mathrm{REY}=0.057 \times\left[\mathrm{P}_{2} \mathrm{O}_{5}\right]+67.6$ & 0.91 \\
2 & $\sum \mathrm{REY}=0.055 \times\left[\mathrm{P}_{2} \mathrm{O}_{5}\right]+0.001 \times\left[\mathrm{Al}_{2} \mathrm{O}_{3}\right]-45.0$ & 0.93 \\
3 & $\sum \mathrm{REY}=0.056 \times\left[\mathrm{P}_{2} \mathrm{O}_{5}\right]+0.001 \times\left[\mathrm{Al}_{2} \mathrm{O}_{3}\right]-0.002 \times[\mathrm{MnO}]-32.0$ & 0.93 \\
4 & $\sum \mathrm{REY}=0.058 \times\left[\mathrm{P}_{2} \mathrm{O}_{5}\right]+0.001 \times\left[\mathrm{Al}_{2} \mathrm{O}_{3}\right]-30.9$ & 0.97 \\
\hline
\end{tabular}

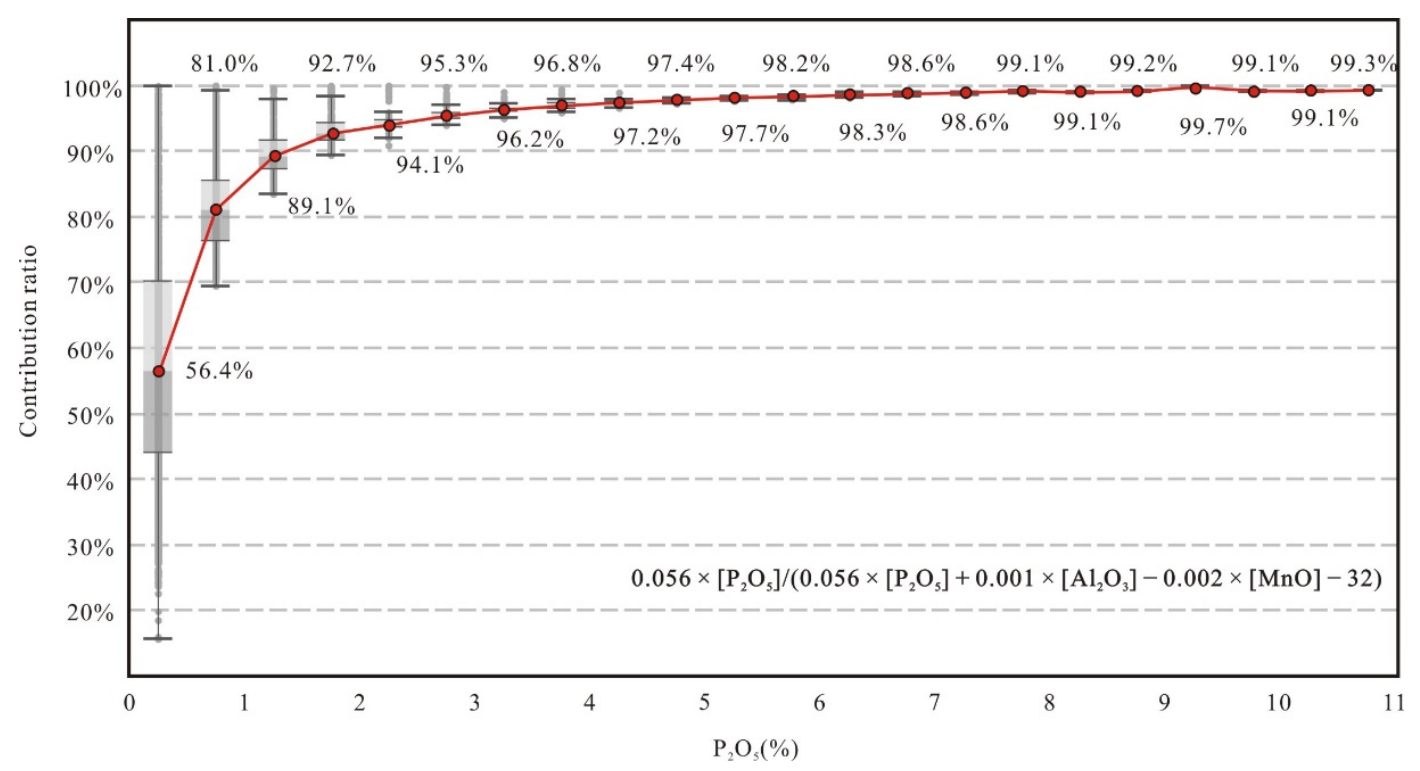

Figure 8. Box-plot diagram of the contribution of phosphate components with different $\mathrm{P}_{2} \mathrm{O}_{5}$ contents to REY enrichment. Using $0.056 \times\left[\mathrm{P}_{2} \mathrm{O}_{5}\right] /\left(0.056 \times\left[\mathrm{P}_{2} \mathrm{O}_{5}\right]+0.001 \times\left[\mathrm{Al}_{2} \mathrm{O}_{3}\right]-0.002 \times[\mathrm{MnO}]-32.0\right)$ to represent the contribution of phosphate components to REY enrichment in deep-sea sediments, the contribution of phosphate components to $\Sigma$ REY in each sample is calculated. The $\mathrm{P}_{2} \mathrm{O}_{5}$ content was divided into 22 groups at intervals of 0.5 , and the median of the box-plot was used to indicate the content trend of each group of data.

A small amount of data shows outliers with a low $\sum \mathrm{REY} / \mathrm{P}_{2} \mathrm{O}_{5}$ ratio; these represent the "REY-poor phosphate component". For example, there are samples with $\mathrm{P}_{2} \mathrm{O}_{5}$ of $6.05 \%$ from site 573B, but with $\sum R E Y$ of only 665 ppm (i.e., $~ 3000$ ppm lower than the regression line; Figure 9). It is more meaningful to understand the relationship between $\sum R E Y$ and REY-rich phosphate components by excluding the data of the REY-poor phosphate component. Through data screening and iterative calculation of new data, this study uses $\sum R E Y=(0.058 \pm 0.018) \times\left[\mathrm{P}_{2} \mathrm{O}_{5}\right]+(0.001 \pm 0.001) \times\left[\mathrm{Al}_{2} \mathrm{O}_{3}\right]+(20 \pm 65)$ as the basis for discriminating between the high REY, REY-rich phosphate, and REY-poor phosphate components (Figure 9). On this basis, 169 data points are REY-poor phosphate (2.8\% of the total). A linear regression analysis of $\sum \mathrm{REY}$ with $\mathrm{P}_{2} \mathrm{O}_{5}$ and $\mathrm{Al}_{2} \mathrm{O}_{3}$ was carried out after excluding the data of REY-poor phosphate; model 4 was obtained, and the $\mathrm{R}^{2}$ is greatly improved. In this study, high REY phosphate is actually a special kind of REY-rich phosphate, which belongs to abnormal data in statistics. It can be interpreted as the extra contribution of REY-rich components (such as Fe-Mn micronodules) to REY enrichment, resulting in higher $\mathrm{REY} / \mathrm{P}_{2} \mathrm{O}_{5}$ ratio. 


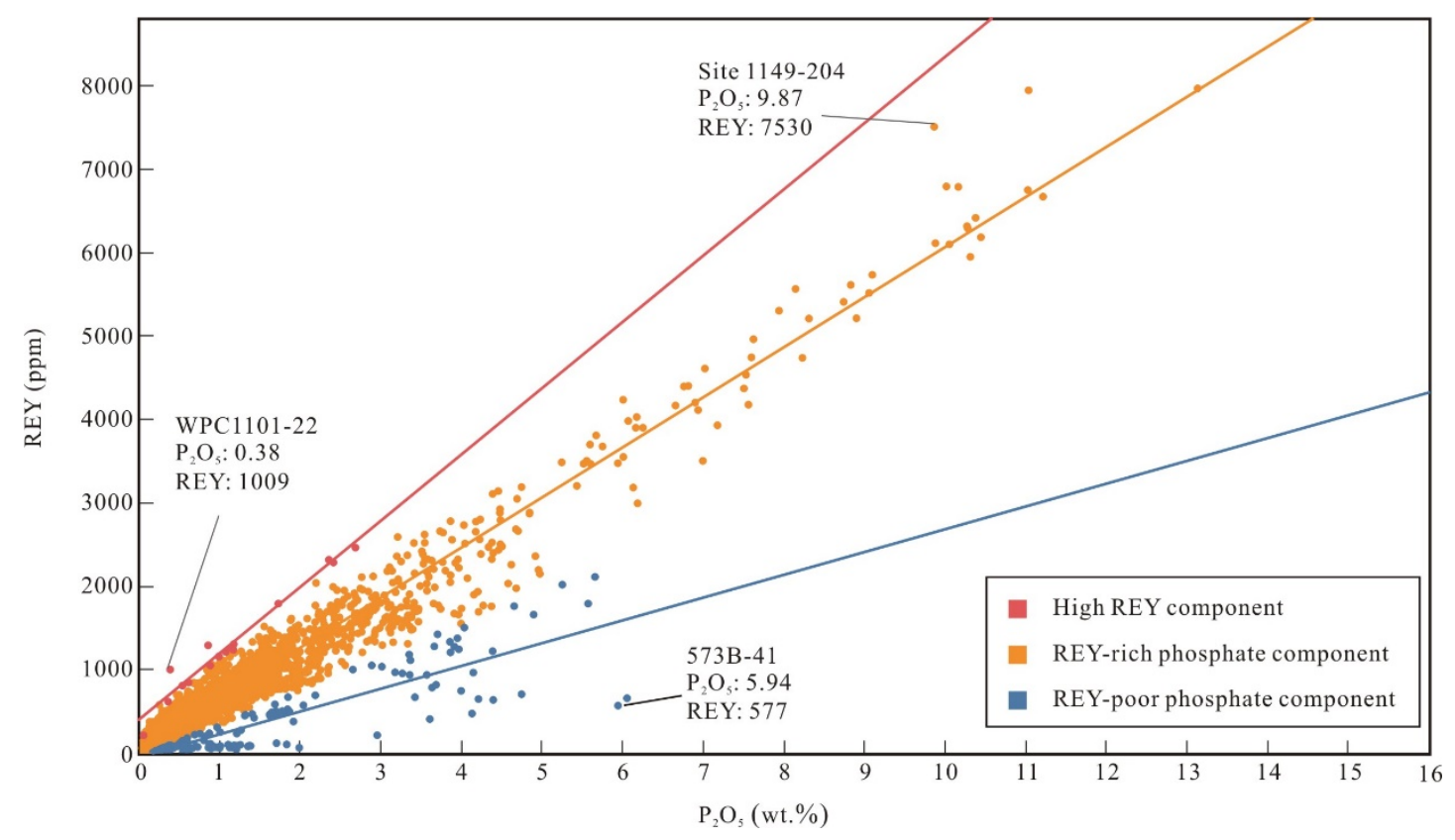

Figure 9. According to the $\sum R E Y, P$ content, and Al content, sediment samples can be divided into a high REY component, REY-rich phosphate component, and REY-poor phosphate component. Data sources as in Figure 1.

\section{Enrichment Mechanism of REY by Phosphate Components}

\subsection{REY Enrichment Complete Near the Seawater/Sediment Interface}

Seawater $\mathrm{Nd}$ isotopic ratios are distinct in each of the modern ocean basins because of inputs of regionally distinct $\mathrm{Nd}$ isotopes from the continents and the short residence time ( $\sim 300$ to $\sim 600$ year) of $\mathrm{Nd}$ in the ocean relative to the ocean mixing time $(\sim 1500$ year) $[41,42]$. Microscopic observations show that the REY-rich deep-sea sediments are rich in bioapatite particles, mainly composed of fish teeth and bone fragments $[1,19,24,43]$. Bioapatite can record $\mathrm{Nd}$ isotopic information of bottom seawater at the time of deposition, and can even be used as a water mass tracer [41]. The hydroxyapatite of living fish teeth contains parts per billion (ppb) levels of $\mathrm{Nd}$, but the hydroxyfluorapatite of fossil teeth typically contains 100-500 ppm Nd [44]. Living phosphate bones and tissues have extremely low $\sum R E Y$. The bones and teeth after biological death will undergo crystal-chemical changes in the early diagenesis process under the influence of the external environment, and the converted bioapatite will have a highly enriched $\sum$ REY $[23,45,46]$. This supports the idea that REY are adsorbed or incorporated during early diagenesis while pore fluids are still in exchange with seawater. As Nd isotopes vary with depth in the water column $[47,48]$, the isotopic ratio of $\mathrm{Nd}$ incorporated in vivo should vary with the depth habitat of the fish species [49].

Some studies suggest that REY enrichment by the phosphate component in the sediment column may be accomplished at a deep depth [36,46]. However, the REY content and relative content data show that REY enrichment of the phosphate component mainly occurs near the seawater/sediment interface. According to the analysis results of bioapatite particles selected from different layers, $\sum R E Y$ varies greatly. The content of $\sum R E Y$ in bioapatite does not increase with depth or burial time $[3,24,36]$. Although the $\sum R E Y$ of bioapatite fluctuate, it is obviously not related to the sedimentary layers. As mentioned above, $2 R E Y$ mainly depends on the content of P in deep-sea sediments (Figure 3). Martin and Scher (2004) studied Nd isotopes and contents in fossil fish teeth and suggested that teeth preserve an early diagenetic signal that represents the $\mathrm{Nd}$ from the bottom water [44]. Fe-Mn oxyhydroxide, organic debris, and other particulate matter that settled to the seafloor have pre-enriched REY, which then easily released the REY at the sediment-seawater interface, providing the phosphate component for the enrichment of REY [8]. 
The $\sum R E Y$ in seawater vary with depth and location, and the REY patterns are relatively stable. However, the REY patterns of pore water are obviously variable, especially for deep layer pore water [28]. The REY patterns of REY-rich deep-sea sediments are similar to those of bottom seawater, but quite different from those of pore water [28]. REY patterns preserved in fossil fish teeth indicate that teeth from deep-sea settings record seawater compositions $[19,24,36]$. These results confirm that REY enrichment during early diagenesis is still in communication with seawater.

In particular, REY is highly particle reactive and has a low content in solution. As a result, the $\sum R E Y$ in pore fluids is extremely low, and is insufficient to provide a material basis for the REY enrichment of the phosphate component [44]. Both high and low temperature studies consistently illustrate that $\mathrm{Nd}$ isotopes are resistant to alteration during post-magmatic water-rock interactions, nor are they mobilized during metamorphic mineralization of Precambrian granitic gneisses [50,51]. One explanation for the resistance of $\mathrm{Nd}$ isotopes to alteration is the low $\sum R E Y$ in circulating fluids relative to the contents in the minerals themselves [44]. Data from sites 1090 [44] and P10 (unpublished) in the Pacific Ocean also demonstrate that fish teeth record short-lived, rapid variations in the $\mathrm{Nd}$ isotopic composition of seawater. These rapid variations suggest that the isotopic signal has not been blurred by diagenetic alteration. These data imply that teeth incorporate or adsorb REY during very early diagenesis and that the content of the REY does not alter with time and/or burial.

Thus, the fact that the $\sum R E Y$ do not increase with depth suggests that there is no source of REY for pore fluids. Instead, REY are introduced to the system from seawater at the seawater/sediment interface. During burial, much of REY is removed from pore fluids by fish teeth, but little is added through diagenesis.

\subsection{Influencing Factors of REY Enrichment}

Not all of the marine phosphate component has high $\Sigma R E Y$; in particular, the shallow water phosphate component generally has low $\Sigma$ REY. For example, the $\sum$ REY of continental marginal bioapatite is generally low, reflective of the relatively fast sedimentation rate. The REY enrichment by the phosphate component mainly occurs within seafloor sediments; the REY patterns are complicated and diverse, and differ from the enrichment process of REY by deep-sea sediments $[46,52,53]$. Moreover, the $\sum R E Y$ of shallow-water phosphorite is not high. A comparison study of 75 samples from around the world shows that the $\sum R E Y$ of marine phosphorites is 360 ppm on average, while the $\mathrm{P}_{2} \mathrm{O}_{5}$ content is $25.1 \%$ on average [39]. In addition, according to the new division mentioned above, $2.8 \%$ of the samples in deep-sea sediments also contain REY-poor phosphate. P enrichment is the basis of REY enrichment in deep-sea sediments, but not all of them can eventually form REY-rich phosphate. Compared with the material composition and formation environment of the phosphate component in shallow water, the REY enrichment mechanism of deepsea sediments can be understood as having three stages: P enrichment, formation of REY-rich phosphate, and REY-rich phosphate re-enrichment. The relationships among P accumulation, sedimentation rate, redox conditions, $\sum R E Y$ of bottom seawater, sediment type, and bottom currents on the REY enrichment of deep-sea sediments is illustrated in Figure 10. 


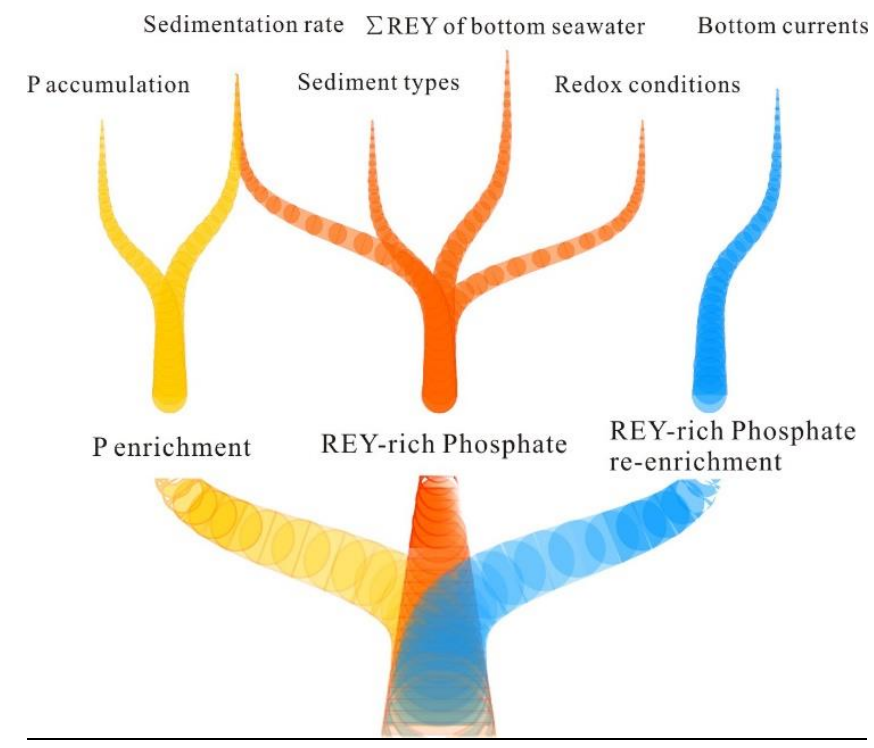

Figure 10. Schematic diagram of the factors influencing REY enrichment in deep-sea sediments and their correlations. REY enrichment can be understood as three important processes: P enrichment, the formation of REY-rich phosphate, and the physical re-enrichment of REY-rich phosphate. The accumulation, of P sedimentation rate, $\Sigma$ REY of bottom seawater, sediment type, redox conditions, and bottom currents have different effects on REY enrichment. The relationships among them are connected by the branches.

REY enrichment in deep-sea sediments firstly depends on the precipitation and enrichment of $\mathrm{P}$. The $\mathrm{P}$ enrichment includes $\mathrm{P}$ adsorption by organic matter and Fe-Mn particles, as well as the chemical precipitation of phosphate from seawater and pore water. After diagenesis, most of the $\mathrm{P}$ is retained in the form of calcium phosphate [54]. The content of microfish tooth bone is an important indicator of REY-rich deep-sea sediments. Therefore, some studies directly suggest that bioapatite is the key to REY enrichment of deep-sea sediments $[3,19]$. The distribution of REY-rich deep-sea sediments on the seafloor and chlorophyll in the surface seawater shows that REY-rich deep-sea sediments mainly develop in low- and middle-latitude areas with low biological primary productivity. The trajectory of a REY-rich sediment site since 30 Ma shows that it is located in a similar marine environment, which indicates that $\mathrm{P}$ enrichment in REY-rich sediment does not occur in areas with high organic $P$ deposition flux (Figure 1). The $P$ enrichment in deep-sea sediments requires a relatively low content of other components, especially a lack of rapidly accumulating calcareous and siliceous biological components. The main components of the P-rich deep-sea sediments found to date are clay or phillipsite clay, indicating extremely slow sedimentation rate environments [33]. According to our investigation, it is true that REY-rich deep-sea sediments are developed in places with relatively low sedimentation rates (Table S2).

On the one hand, a low sedimentation rate is beneficial to the accumulation of the phosphate component in deep-sea sediments per unit volume; on the other hand, it provides sufficient time for the phosphate component to enrich the REY. If the only source of $\Sigma R E Y$ to the fish teeth is seawater, one might expect the teeth in contact with seawater for the longest time (i.e., the slowest sedimentation rates) to have the highest $\Sigma R E Y$ [44]. Yasukawa et al. (2016) quantitatively showed that seawater can contain the flux of REY precipitation required to explain the observed very high $\Sigma$ REY (>1000 ppm) in bulk REY-rich deep-sea sediments with a sedimentation rate of less than $\sim 0.5 \mathrm{~m} / \mathrm{Myr}$ [8]. Kato et al. (2011) used a diagram of $\sum R E Y$ vs. sedimentation rate to visually show that REY-rich deep-sea sediments develop in low sedimentation rate environments [4]. When the sedimentation rate is sufficiently low, the phosphate component can be exposed to the surface for a long time to obtain seawater REY [5]. Martin and Scher (2004) compared the Nd content and 
sedimentation rate of the fish tooth fossils in four sedimentary sites in the Pacific. There was a certain correlation between $\mathrm{Nd}$ content and sedimentation rate, and the tooth with the highest $\mathrm{Nd}$ developed at the lowest sedimentation rate [44]. Deep-sea sediments with low sedimentation rates often contain a large number of phillipsite particles, which is also consistent with a slow sedimentation rate $[55,56]$. However, phillipsite itself has a low $\sum R E Y$, which explains that the REY-rich deep-sea sediments are often accompanied by phillipsite.

Owing to dissolved oxygen supplementation by bottom currents, the oxygen fugacity of the deep-sea environment is relatively high. Surface deep-sea sediments have high oxygen fugacities, and the probability of remineralization is low [28]. Continental margin sediments generally display relatively narrow redox conditions (e.g., only $1 \mathrm{~mm}$-thick of sediments in Buzzard bay) [57]. The high REY enrichment in deep-sea sediments requires a continuous supply of REY by the bottom seawater, and reduction conditions hinder the recharge of REY from overlying seawater to the sediment-seawater interface. Low sedimentation rate, low organic components, and relatively high oxygen fugacity are interdependent. Oxidation conditions can promote P deposition and REY enrichment [28].

The $\sum R E Y$ in the ocean water column tends to increase with water depth, and the $\sum R E Y$ of deep-sea water is generally several times that of surface sea water $[28,38,58]$. The REY-rich sediments are mainly distributed in the deep-sea environment below CCD, which prevents the rapid accumulation of dilutive components with low $\sum$ REY (e.g., biogenic carbonate and silica) [8]. Phosphorites developed in shallow water environments are located in carbonate sedimentary environments, and phosphate roots directly replace carbonate, which will inevitably prompt REY to enter the phosphate component, resulting in a low $\sum \mathrm{REY} / \mathrm{P}_{2} \mathrm{O}_{5}$ ratio of seamount phosphorites [12]. For example, Pan et al. (2004) studied the microscopic characteristics and carbon isotope characteristics of seamount phosphorites, and found that carbonates and other calcium-bearing materials had been replaced by phosphates to a varying degree. Bioapatite such as conodont developed in shallow water limestone also demonstrates that phosphates are of replacement origin, with a low $\Sigma \mathrm{REY} / \mathrm{P}_{2} \mathrm{O}_{5}$ ratio [59].

The erosion of deep-sea sediments may play an important role in the formation of highly REY-rich sediment layers. Tanaka et al. (2020) produce a chemostratigraphic scheme for 1240 sediment samples from 49 piston sites collected within the Minamitorishima exclusive economic zone. The chemostratigraphy reveals that highly REY-enriched layers formed at least three times, and that almost all of these layers were accompanied by erosion during deposition [6]. The grain size distributions of bulk sediments from the REY-enriched layers were bimodal, with peaks at fine $(\sim 4 \mu \mathrm{m})$ and coarse $(\sim 40-80 \mu \mathrm{m})$ sizes. Calcium phosphate and phillipsite were the major components of the coarse-grained portions of these REY-enriched layers [43]. Enhancement of bottom currents can produce selective accumulation of coarse biogenic Ca phosphate (BCP) grains enriched in REY, resulting in the formation of REY-enriched layers $[6,43]$. However, it should be noted that if the bottom current was sufficiently strong during deposition, it could have hampered the accumulation of BCP grains or even eroded the sediments as a whole [6].

\section{Conclusions}

1. REY-rich deep-sea sediments are mainly distributed in the middle Indian Ocean basin, Northwest Pacific, and southwest Pacific Ocean at middle and low latitudes. The deepsea sediments off Minamitorishima island have the highest $\sum$ REY (7974 ppm), but the surface sediments are generally low in $\sum R E Y$.

2. The carriers of REY include aluminosilicates, Fe-Mn oxyhydroxides, and the phosphate component. Linear regression analysis shows that the quantitative relationship between REY and the three components can be expressed as $\sum R E Y=0.001 \times\left[\mathrm{Al}_{2} \mathrm{O}_{3}\right]$ $-0.002 \times[\mathrm{MnO}]+0.056 \times\left[\mathrm{P}_{2} \mathrm{O}_{5}\right]-32.0$, where $R^{2}=0.93$. The $\sum \mathrm{REY}$ of the phosphate component is $\sim 1-2$ orders of magnitude higher than that of the other two carriers, which is very important for the enrichment of REY. 
3. The $\sum R E Y$ of living phosphate bones and teeth is low, but increases rapidly after death. The content of $\sum R E Y$ in bioapatite does not increase with depth. The REY patterns of REY-rich deep-sea sediments are similar to those of bottom seawater, but quite different from those of pore water. The $\sum R E Y$ in pore fluids is extremely low, and is insufficient to provide a material basis for REY enrichment. These phenomena indicate that the enrichment of REY is mainly completed near the seawater/sediment interface.

4. REY enrichment is the result of comprehensive action. Low sedimentation rate is beneficial to the accumulation of $\mathrm{P}$ in unit volume sediments and the recharge of REY by bottom seawater. The high $\sum R E Y$ in bottom seawater provides a high $\sum R E Y$ background value for the enrichment of the seafloor phosphate component. Non-carbonate depositional environments avoid the formation of REY-poor phosphates by replacing carbonate with phosphate. In addition, the sorting effect of the bottom current on deep-sea sediments further accumulates REY-rich phosphates to form REY-rich deposits.

Supplementary Materials: The following are available online at https:/ www.mdpi.com/2075-163 X/11/2/196/s1, Table S1: The content of Major element (\%) and REY (ppm) of deep-see sediments complied from global Ocean, Table S2: $\sum$ REY of the surface, average value of surface layer within $3 \mathrm{~m}$ and maximum value of site sample, Table S3: Element correlation coefficient of deep-sea sediments off Minamitorishima Island. Data is is calculated from [6].

Author Contributions: Data curation, F.W.; formal analysis and methodology, G.H. and X.D.; resources, Z.W.; software, H.Y.; writing-original draft, J.R.; writing-review \& editing, Y.L. All authors have read and agreed to the published version of the manuscript.

Funding: This research was funded by the National Natural Science Foundation of China (42002085, 41702096 and 41922014), China Ocean Mineral Resources R \& D Association Research Program (DY135-R2-1-05), Key Special Project for Introduced Talents Team of Southern Marine Science and Engineering Guangdong Laboratory (Guangzhou) (GML2019ZD0106), Project of the Geological Survey of China (DD20191009), and fundamental Research Funds for the Institute of Geology, Chinese Academy of Geological Sciences (Grant J2004).

Institutional Review Board Statement: Not applicable.

Informed Consent Statement: Not applicable.

Data Availability Statement: Not applicable.

Acknowledgments: The authors thank the two anonymous reviewers for providing useful suggestions and comments on this manuscript.

Conflicts of Interest: The authors declare they have no conflict of interest.

\section{References}

1. Yasukawa, K.; Miyazaki, T.; Vaglarov, B.; Chang, Q.; Ueki, K.; Toyama, C.; Kimura, J.-I.; Tanaka, E.; Nakamura, K.; Fujinaga, K.; et al. Statistic and Isotopic Characterization of Deep-Sea Sediments in the Western North Pacific Ocean: Implications for Genesis of the Sediment Extremely Enriched in Rare-Earth Elements. Geochem. Geophys. Geosyst. 2019, 20, 3402-3430. [CrossRef]

2. Borst, A.M.; Smith, M.P.; Finch, A.A.; Estrade, G.; Villanova-de-Benavent, C.; Nason, P.; Marquis, E.; Horsburgh, N.J.; Goodenough, K.M.; Xu, C.; et al. Adsorption of rare earth elements in regolith-hosted clay deposits. Nat. Commun. 2020, 11, 4386. [CrossRef]

3. Takaya, Y.; Yasukawa, K.; Kawasaki, T.; Fujinaga, K.; Ohta, J.; Usui, Y.; Nakamura, K.; Kimura, J.-I.; Chang, Q.; Hamada, M. The tremendous potential of deep-sea mud as a source of rare-earth elements. Sci. Rep. 2018, 8, 1-8. [CrossRef]

4. Kato, Y.; Fujinaga, K.; Nakamura, K.; Takaya, Y.; Kitamura, K.; Ohta, J.; Toda, R.; Nakashima, T.; Iwamori, H. Deep-sea mud in the Pacific Ocean as a potential resource for rare-earth elements. Nat. Geosci. 2011, 4, 535-539. [CrossRef]

5. Yasukawa, K.; Nakamura, K.; Fujinaga, K.; Machida, S.; Ohta, J.; Takaya, Y.; Kato, Y. Rare-earth, major, and trace element geochemistry of deep-sea sediments in the Indian Ocean: Implications for the potential distribution of REY-rich mud in the Indian Ocean. Geochem. J. 2015, 49, 621-635. [CrossRef]

6. Tanaka, E.; Nakamura, K.; Yasukawa, K.; Mimura, K.; Fujinaga, K.; Iijima, K.; Nozaki, T.; Kato, Y. Chemostratigraphy of deep-sea sediments in the western North Pacific Ocean: Implications for genesis of mud highly enriched in rare-earth elements and yttrium. Ore. Geol. Rev. 2020, 119, 103392. [CrossRef] 
7. Zhang, X.; Tao, C.; Shi, X.; Li, H.; Huang, M.U.; Huang, D. Geochemical characteristics of REY-rich pelagic sediments from the GC02 in central Indian Ocean Basin. J. Rare Earths 2017, 35, 1047-1058. [CrossRef]

8. Yasukawa, K.; Nakamura, K.; Fujinaga, K.; Iwamori, H.; Kato, Y. Tracking the spatiotemporal variations of statistically independent components involving enrichment of rare-earth elements in deep-sea sediments. Sci. Rep. 2016, 6, 29603. [CrossRef] [PubMed]

9. $\quad$ Iijima, K.; Yasukawa, K.; Fujinaga, K.; Nakamura, K.; Machida, S.; Takara, Y.; Ohta, J.; Haraguchi, S.; Nishio, Y.; Usui, Y.; et al. Discovery of extremely REY-rich mud in the western North Pacific Ocean. Geochem. J. 2016, 50, 557-573. [CrossRef]

10. Ren, J.; Yao, H.; Zhu, K. Enrichment mechanisms of rare earth elements and yttrium for Deep-sea mud from Clarion-Clipperton Region, East Pacific Ocean. Earth Sci. Front. 2015, 22, 200-211, (In Chinese with English Abstract). [CrossRef]

11. Pattan, J.N.; Parthiban, G. Geochemistry of ferromanganese nodule-sediment pairs from Central Indian Ocean Basin. J Asian Earth Sci 2011, 40, 569-580. [CrossRef]

12. Ren, J.; He, G.; Zhu, K.; Deng, X.; Liu, J.; Fu, P.; Yao, H.; Yang, S.; Li, H.; Sun, W. REY-rich Phosphate and Its Effects on the Deep-sea Mud Mineralization. Acta Geol. Sin. 2017, 91, 1312-1325, (In Chinese with English Abstract).

13. Deng, Y.; Ren, J.; Guo, Q.; Cao, J.; Wang, H.; Liu, C. Geochemistry characteristics of REY-rich sediment from deep sea in Western Pacific, and their indicative significance. Acta Pet. Sin. 2018, 34, 733-747, (In Chinese with English Abstract).

14. Mimura, K.; Nakamura, K.; Yasukawa, K.; Machida, S.; Ohta, J.; Fujinaga, K.; Kato, Y. Significant impacts of pelagic clay on average chemical composition of subducting sediments: New insights from discovery of extremely rare-earth elements and yttrium-rich mud at Ocean Drilling Program Site 1149 in the western North Pacific Ocean. J. Asian. Earth Sci. 2019, 186, 104059. [CrossRef]

15. Zhang, X.; Huang, M.; Shi, X.; Huang, D. The geochemical characteristics of rare earth elements rich deep sea deposit of Core GC11 in central Indian Ocean Basin. Haiyang Xuebao 2019, 41, 51-61, (In Chinese with English Abstract). [CrossRef]

16. Müller, R.D.; Sdrolias, M.; Gaina, C.; Roest, W.R. Age, spreading rates, and spreading asymmetry of the world's ocean crust. Geochem. Geophy. Geosy. 2008, 9, 1-42. [CrossRef]

17. D'Hondt, S.; Inagaki, F.; Zarikian, C.; Abrams, L.; Dubois, N.; Engelhardt, T.; Evans, H.; Ferdelman, T.; Gribsholt, B.; Harris, R.; et al. Presence of oxygen and aerobic communities from seafloor to basement in deep-sea sediment. Nat. Geosci. 2015, 8, 1-6. [CrossRef]

18. Takebe, M. Carriers of Rare Earth Elements in Pacific Deep-Sea Sediments. J. Geol. 2005, 113, 201-215. [CrossRef]

19. Kon, Y.; Hoshino, M.; Sanematsu, K.; Morita, S.; Tsunematsu, M.; Okamoto, N.; Yano, N.; Tanaka, M.; Takagi, T. Geochemical Characteristics of Apatite in Heavy REE-rich Deep-Sea Mud from Minami-Torishima Area, Southeastern Japan. Resour. Geol. 2014, 64, 47-57. [CrossRef]

20. Wang, F.; He, G.; Sun, X.; Yang, Y.; Zhao, T. The host of REE+Y elements in deep-sea sediments from the Pacific Ocean. Acta Pet. Sin. 2016, 32, 2057-2068, (In Chinese with English Abstract).

21. Ren, J.; Deng, Y.; Lai, P.; He, G.; Wang, F.; Yao, H.; Deng, X.; Liu, Y. Geochemical characteristics and genesis of polymetallic nodules in the investigation area in Pacific. Earth Sci. Front. 2020. (In Chinese with English Abstract). [CrossRef]

22. Bau, M.; Schmidt, K.; Koschinsky, A.; Hein, J.; Kuhn, T.; Usui, A. Discriminating between different genetic types of marine ferro-manganese crusts and nodules based on rare earth elements and yttrium. Chem. Geol. 2014, 381, 1-9. [CrossRef]

23. Kashiwabara, T.; Toda, R.; Nakamura, K.; Yasukawa, K.; Fujinaga, K.; Kubo, S.; Nozaki, T.; Takahashi, Y.; Suzuki, K.; Kato, Y. Synchrotron X-ray spectroscopic perspective on the formation mechanism of REY-rich muds in the Pacific Ocean. Geochim. Cosmochim. Acta 2018, 240, 274-292. [CrossRef]

24. Liao, J.; Sun, X.; Li, D.; Sa, R.; Lu, Y.; Lin, Z.; Xu, L.; Zhan, R.; Pan, Y.; Xu, H. New Insights into Nanostructure and Geochemistry of Bioapatite in REE-Rich Sediments: LA-ICP-MS, TEM, and Z-Contrast Imaging Studies. Chem. Geol. 2019, 512, 58-68. [CrossRef]

25. Paul, S.A.L.; Volz, J.B.; Bau, M.; Köster, M.; Kasten, S.; Koschinsky, A. Calcium phosphate control of REY patterns of siliceousooze-rich deep-sea sediments from the central equatorial Pacific. Geochim. Cosmochim. Acta 2019, 251, 56-72. [CrossRef]

26. Ohta, J.; Yasukawa, K.; Nozaki, T.; Takaya, Y.; Mimura, K.; Fujinaga, K.; Nakamura, K.; Usui, Y.; Kimura, J.-I.; Chang, Q.; et al. Fish proliferation and rare-earth deposition by topographically induced upwelling at the late Eocene cooling event. Sci. Rep. 2020, 10, 1-11. [CrossRef]

27. Paytan, A.; McLaughlin, K. The Oceanic Phosphorus Cycle. Chem. Rev. 2007, 107, 563-576. [CrossRef]

28. Deng, Y.; Ren, J.; Guo, Q.; Cao, J.; Wang, H.; Liu, C. Rare earth element geochemistry characteristics of seawater and porewater from deep sea in western Pacific. Sci. Rep. 2017, 7, 16539. [CrossRef] [PubMed]

29. Dutkiewicz, A.; Judge, A.; Müller, D. Environmental predictors of deep-sea polymetallic nodule occurrence in the global ocean. Geology 2020, 48, 293-297. [CrossRef]

30. Yasukawa, K.; Liu, H.; Fujinaga, K.; Machida, S.; Haraguchi, S.; Ishii, T.; Nakamura, K.; Kato, Y. Geochemistry and mineralogy of REY-rich mud in the eastern Indian Ocean. J. Asian Earth Sci. 2014, 93, 25-36. [CrossRef]

31. Menendez, A.; James, R.; Roberts, S.; Peel, K.; Connelly, D. Controls on the distribution of rare earth elements in deep-sea sediments in the North Atlantic Ocean. Ore. Geol. Rev. 2017, 87, 100-113. [CrossRef]

32. Zhang, X.; Shi, X.; Huang, M.; Teng, G.; Ma, S.; Huang, D. Some Problems in Research of Deep Sea Rare Earth Rich Deposit. J. Chin. Soc. Rare Earths 2019, 37, 517-529, (In Chinese with English Abstract). [CrossRef]

33. Zhu, K.; Ren, J.; Wang, H.; Lu, H.F. Enrichment Mechanism of REY and Geochemical Characteristics of REY-rich Pelagic Clay from the Central Pacific. Earth Sci. 2015, 40, 1052-1060, (In Chinese with English Abstract). 
34. Toyoda, K.; Nakamura, Y.; Masuda, A. Rare earth elements of Pacific pelagic sediments. Geochim. Cosmochim. Acta 1990, 54, 1093-1103. [CrossRef]

35. Zhu, K.; Ren, J.; Wang, H. Geochemical Characteristics and Chemical Classification of REY-Rich Pelagic Sediments from the Central Pacific Ocean. Acta Geosci. Sin. 2016, 37, 287-293, (In Chinese with English Abstract).

36. Toyoda, K.; Tokonami, M. Diffusion of rare-earth elements in fish teeth from deep-sea sediments. Nature 1990, 345, 607-609. [CrossRef]

37. Gromet, L.P.; Dymer, R.F.; Haskin, L.A.; Korotev, R.L. The "North American shale composition": Its complication, major and trace element characteristics. Geochim. Cosmochim. Acta 1984, 48, 2469-2482. [CrossRef]

38. Ren, J.; Deng, X.; Deng, Y.; He, G.; Wang, F.; Yao, H. Rare Earth Element Characteristics and Its Geological Implications for Seawater from Cobalt-Rich Ferromanganese Crust Exploration Contract Area of China. Earth Sci. 2019, 44, 3529-3540, (In Chinese with English Abstract). [CrossRef]

39. Hein, J.R.; Koschinsky, A.; Mikesell, M.; Mizell, K.; Glenn, C.R.; Wood, R. Marine Phosphorites as Potential Resources for Heavy Rare Earth Elements and Yttrium. Minerals 2016, 6, 88. [CrossRef]

40. Liu, Z.; Wu, Y.; Zhu, K.; Li, W.; Zhu, W.; Qiu, X. Occurrence State and Leaching of Rare Earth in Pelagic Clay from Central Pacific. J. Chin. Soc. Rare Earths 2015, 33, 506-512, (In Chinese with English Abstract).

41. Horikawa, K.; Martin, E.E.; Asahara, Y.; Sagawa, T. Limits on conservative behavior of Nd isotopes in seawater assessed from analysis of fish teeth from Pacific core tops. Earth Planet Sci. Lett. 2011, 310, 119-130. [CrossRef]

42. Alibo, D.S.; Nozaki, Y. Rare earth elements in seawater: Particle association, shale-normalization, and Ce oxidation. Geochim. Cosmochim. Acta 1999, 63, 363-372. [CrossRef]

43. Ohta, J.; Yasukawa, K.; Machida, S.; Fujinaga, K.; Nakamura, K.; Takaya, Y.; Iijima, K.; Suzuki, K.; Kato, Y. Geological factors responsible for REY-rich mud in the western North Pacific Ocean: Implications from mineralogy and grain size distributions. Geochem. J. 2016, 50, 1-13. [CrossRef]

44. Martin, E.E.; Scher, H.D. Preservation of seawater Sr and Nd isotopes in fossil fish teeth: Bad news and good news. Earth Planet Sci. Lett. 2004, 220, 25-39. [CrossRef]

45. Trotter, J.A.; Eggins, S.M. Chemical systematics of conodont apatite determined by laser ablation ICPMS. Chem. Geol. 2006, 233, 196-216. [CrossRef]

46. Elderfield, H.; Pagett, R. Rare earth elements in ichthyoliths: Variations with redox conditions and depositional environment. Sci. Total Environ. 1986, 49, 175-197. [CrossRef]

47. Stichel, T.; Frank, M.; Rickli, J.; Haley, B.A. The hafnium and neodymium isotope composition of seawater in the Atlantic sector of the Southern Ocean. Earth Planet Sci. Lett. 2012, 317, 282-294. [CrossRef]

48. Zimmermann, B.; Porcelli, D.; Frank, M.; Rickli, J.; Lee, D.C.; Halliday, A.N. The hafnium isotope composition of Pacific Ocean water. Geochim. Cosmochim. Acta 2009, 73, 91-101. [CrossRef]

49. Martin, E.E.; Blair, S.W.; Kamenov, G.D.; Scher, H.D.; Bourbon, E.; Basak, C.; Newkirk, D.N. Extraction of Nd isotopes from bulk deep sea sediments for paleoceanographic studies on Cenozoic time scales. Chem. Geol. 2010, 269, 414-431. [CrossRef]

50. Franck, P.; Jean-Louis, D.; Christian, P. The Relationship between Petrology and Nd Isotopes as Evidence for Contrasting Anorogenic Granite Genesis: Example of the Corsican Province (SE France). J. Petrol. 1995, 36, 1251-1274.

51. Pagel, M.; Michard, A.; Juteau, M.; Turpin, L. Sm-Nd, Pb-Pb, and Rb-Sr systematics of the basement in the Cigar Lake area, Saskatchewan, Canada. Can. J. Earth Sci. 1993, 30, 731-742. [CrossRef]

52. Lécuyera, C.; Reynardb, B.; Grandjean, P. Rare earth element evolution of Phanerozoic seawater recorded in biogenic apatites Chem. Geol. 2004, 204, 63-102. [CrossRef]

53. Trotter, J.; Barnes, C.; McCracken, A. Rare earth elements in conodont apatite: Seawater or pore-water signatures? Palaeogeogr. Palaeoclimatol. Palaeoecol. 2016, 462, 92-100. [CrossRef]

54. Föllmi, K.B. The phosphorus cycle, phosphogenesis and marine phosphate-rich deposits. Earth Sci. Rev. 1996, 40, 55-124. [CrossRef]

55. Bernat, M.; Bieri, R.H.; Koide, M.; Griffin, J.J.; Goldberg, E.D. Uranium, thorium, potassium and argon in marine phillipsites. Geochim. Cosmochim. Acta 1970, 34, 1053-1071. [CrossRef]

56. Stonecipher, S.A. Origin, distribution and diagenesis of phillipsite and clinoptilolite in deep-sea sediments. Chem. Geol. 1976, 17, 307-318. [CrossRef]

57. Elderfield, H.; Sholkovitz, E.R. Rare earth elements in the pore waters of reducing nearshore sediments. Earth Planet Sci. Lett. 1987, 82, 280-288. [CrossRef]

58. Zheng, X.-Y.; Plancherel, Y.; Saito, M.A.; Scott, P.M.; Henderson, G.M. Rare earth elements (REEs) in the tropical South Atlantic and quantitative deconvolution of their non-conservative behavior. Geochim. Cosmochim. Acta 2016, 177, 217-237. [CrossRef]

59. Pan, J.; Liu, S.; Yang, Y.; Liu, X. The Origin and Formation Environment of Phosphates on Submarine Guyots of the Pacific Ocean. Acta Geosci. Sin. 2004, 25, 453-458, (In Chinese with English Abstract). 